\title{
MELITOPALYNOLOGICAL AND ANTIMICROBIAL PROPERTIES OF HONEYS FROM ELAZIĞ (E TURKEY)
}

\author{
N. GÜR, M. DIĞRAK, D. ÇOBANOĞLU and N. DILSIZ \\ Firat Üniversitesi, Fen-Edebiyat Fakültesi, Biyoloji Bölümü Elazı̆̆, Turkey; E-mail: \\ ngur@firat.edu.tr
}

(Received 15 March, 2001)

\begin{abstract}
In this study, the pollen analyses and antimicrobial effect were conducted in honey samples, which were collected from seven localities where apiculture has intensively been practiced. Upon pollen analyses of 16 different plants have been determined. The plants contributing nectar to honey samples in Elazı $\breve{g}$ were found as follows; Fabaceae: Astragalus, Trifolium, Vicia, Onobrychis; Asteraceae: Centaurea triumfettii, Carduus, Xeranthemum, Helianthus annuus; Lamiaceae: Salvia, Mentha; Rosaceae: Rubus, Prunus; Vitaceae: Vitis; Apiaceae: Daucus; Zygophyllaceae: Peganum harmala; Ranunculaceae: Ranunculus. The honey samples have inhibited the growth of bacteria used in our work at varying degrees. None of the samples had any antifungal effect against Candida albicans FMC-17 and Saccharomyces cerevisiae UAG-102.
\end{abstract}

Key words: honey, pollen grains, antimicrobial properties

\section{INTRODUCTION}

Honey is one of the most important nutrition resources for people over centuries. Nowadays, a lot of studies are going on to improve both quality and productivity of this natural nutrition. These studies are mainly intensified on observing the pure strain of bee and plants, which can produce more nectar. The identification of nectar bearing plants for honey can be analysed by melitopalynological studies. Using melitopalynological studies (Sorkun and İnceoğlu 1984, Sorkun and Yuluğ 1985, Göçmen and Gökçeoğlu 1991, Gemici 1990) the nectar plants of a few regions of Turkey have been identified. However, no work has been done in Eastern Turkey before our present work.

Honey is commonly using as a public therapeutic substance in the world (Ali et al. 1991). The antibacterial properties of honey have been known for more than a century (Dustman 1979). The growing of most of bacteria and fungi, which cause a various infections, wounds and bruises, is inhibited by honey. However, no effects have been observed on Pseudomonas aeruginosa and Clostridium oedematiens (Efem et al. 1992). The antibi- 
otic effects of honey on Helicobacter pylori and some pathological bacteria were studied and it was found that honey with $20 \%$ in concentration can inhibits the growing of these studied bacteria (Ali et al. 1991).

The most extensive effect of honey concentration is likely to be at $0.5 \%$ $(\mathrm{v} / \mathrm{v})$. This concentration also has a fungicidal effects on Candida albicans and fungistatic on Penicillum spp. and Aspergillus niger. In agreement with the antimicrobial effects of honey, $0.5 \%$ concentration is equal to $0.5 \%$ phe$\mathrm{nol}(\mathrm{w} / \mathrm{v}), 2 \mathrm{mg} / \mathrm{ml}$ streptomycine and 30 units $/ \mathrm{ml}$ of nistatin (ObesekiEbor et al. 1983).

Some components of honey samples have been extracted by ethanol/ether and separated by using thin-layer chromatography (TLC). A significant amount of methyl 3,4,5-trimethoxyl-4-hidroxy-benzoate (methyl syringate) was detected from the study of the antibacterial effects of this separated components. In addition to that, the effects of methyl 3,4,5-trimethoxyl-benzoate, 3,4,5-trimethoxyl-benzoic acid and methyl ester have been studied against to Staphylococcus aureus. It was found that, methyl syringate, has more effective than the others (Russel et al. 1990).

In present study, it was aimed to investigate the palynological characters and the main component of antimicrobial effects of honey samples from the province of Elazığ (E Turkey) which has an important resource of honeys in Turkey.

\section{MATERIAL AND METHODS}

\section{Pollen analysis}

The study was carried out on honey samples obtained from 7 different locations in Elazığ region whose addresses were communicated to us by the provincial Agricultural authorities. The more information was gathered by observing the flora of these areas from which the honey samples originated and discussion with local bee keepers. For the best results of pollen analysis from honey samples, plants were collected around the hives during their blossoming period. As it is known that bees can go away maximum 5-6 km from their hives to collect nectar, the plant samples of all this area were collected. Preparation of the material and analysis were performed according to the method of Wodehouse (Wodehouse 1965, Aytug 1967). The honey samples (500 g) were taken during honey extraction and labelled and stored in bottles of $1000 \mathrm{ml}$ in volume until pollen analysis. 
Pollen of honey samples were prepared, quantified and calculated as described by Louveaux et al. (1978). Honey samples were mixed carefully by using glass-rod. Ten $g$ of each sample was transferred to tube and then $20 \mathrm{ml}$ of $\mathrm{H}_{2} \mathrm{O}$ added and covered by parafilm. Honey samples were then transferred to the water bath of $45^{\circ} \mathrm{C}$ for $10-15 \mathrm{~min}$ with vigorously shaken to be solved. Samples were centrifuged for $30 \mathrm{~min}$ at $\times 4500 \mathrm{rpm}$. The supernatant was taken out at the end of centrifugation period. Pollen grains from pellet were identified and classified according to the taxonomic references (Wodehouse 1965, Aytuğ 1967, Erdtman 1974). An approximate number of pollen per $10 \mathrm{~g}$ honey sample was calculated and their percentage was counted for each sample.

\section{Antimicrobial properties}

The microorganism strains used in this study were obtained from The Culture Collection of Microbiology Department of Firat University, Elazı̆̆. A various strain of bacteria (Bacillus megaterium DSM-32, Bacillus subtilis IMG-22, Escherichia coli ATCC-25922, Staphyloccocus aureus COWAN-1, Pseudomonas aeruginosa DSM-50071, Klebsiella pneumoniae FMCS, Enterobacter aerogenes CCM-2531, Salmonella sp. FMC-20) and fungi (Saccharomyces cerevisiae UAG-102, Candida albicans FMC-17) were tested through this study.

The antimicrobial effects of honey samples were tested by using disc agar method. For this, tubes containing honey samples were left at $37^{\circ} \mathrm{C}$ in a water bath for two hours (Sorkun and Yulug 1985).

The bacteria strains were incubated into Nutrient Buyyon (Difco) at $30^{\circ} \mathrm{C}$ for 18-24 h. On the other hand fungi strains were incubated into Malt Extract Buyyon (Difco) at $25^{\circ} \mathrm{C}$ for $48 \mathrm{~h}$. The aliquots of each culture $(5 \mathrm{ml})$ from the mixture of culture plus sterile Müller Hinton Agar $(10 \mathrm{ml})$ were transferred to the sterile Petri dishes ( $9 \mathrm{~cm}$ in diameter) and mixed gently. A few holes (11 $\mathrm{mm}$ in diameter) were opened in agar plate and $0.1 \mathrm{ml}$ of prepared honey samples and control added to each hole. Agar plates for bacteria were left at $4{ }^{\circ} \mathrm{C}$ for one $\mathrm{h}$ then transferred to $35^{\circ} \mathrm{C}$ for further $18 \mathrm{~h}$. On the other hand, agar plates inoculated with yeast were incubated at $25^{\circ} \mathrm{C}$ for 3-4 days. The inhibition zones were measured in $\mathrm{mm}$ at the end of the incubation period. 


\section{RESULTS AND DISCUSSION}

The honey collected in our research area is called Astragalus honey by local bee keepers. From our study, the pollen of Astragalus sp. was predominant in 5 out of the studied 7 samples (Table 1).

According to this result, Astragalus sp. is a characteristic plant for the producing nectar in Elazığ region. In the other three honey samples, Peganum harmala of the Zygophyllaceae family, Achillea and Xeranthemum of the Asteraceae family were presented predominantly for each sample. Where the pollen of Astragalus sp. was not detected at all in the last sample.

Table 1

Pollen concentration of honey in Elazı̆̆. (Localities: 1 = Baunuşağı, 2 = Harput, 3 = Koparuşağı, $4=$ Maden, 5 = Sivrice, $6=$ Yolçatı, $7=$ Yukarı İçme)

\begin{tabular}{|c|c|c|c|c|c|c|c|}
\hline \multirow[b]{2}{*}{$\begin{array}{l}\text { Plant species / } \\
\text { Localities }\end{array}$} & \multicolumn{7}{|c|}{ Pollen concentration of honey (\%) } \\
\hline & 1 & 2 & 3 & 4 & 5 & 6 & 7 \\
\hline \multicolumn{8}{|l|}{ Fabaceae } \\
\hline Astragalus & 48.6 & 2.9 & 73.1 & 57.2 & 27.0 & 31.7 & - \\
\hline Trifolium & 14.9 & 0.9 & - & 22.9 & 8.0 & 24.2 & 4.8 \\
\hline Vicia & 9.9 & 6.6 & - & - & 2.1 & - & 5.1 \\
\hline Onobrychis & 6.0 & - & 5.2 & - & - & - & - \\
\hline \multicolumn{8}{|l|}{ Asteraceae } \\
\hline Centaurea triumfettii & - & 9.7 & - & - & 10.2 & - & 11.3 \\
\hline Carduus & - & 5.3 & - & - & - & - & 7.2 \\
\hline Xeranthemum & 9.3 & 5.0 & - & 7.2 & 40.5 & 20.8 & 49.9 \\
\hline Helianthus annuus & - & - & - & - & 0.6 & - & 9.0 \\
\hline \multicolumn{8}{|l|}{ Lamiaceae } \\
\hline Salvia & - & 3.7 & 3.4 & 8.8 & 1.0 & - & - \\
\hline Mentha & 2.2 & 0.9 & - & - & - & - & - \\
\hline \multicolumn{8}{|l|}{ Rosaceae } \\
\hline Rubus & 8.7 & - & 18.2 & 2.6 & - & 23.3 & - \\
\hline Prunus & - & 12.6 & - & - & - & - & - \\
\hline \multicolumn{8}{|l|}{ Vitaceae } \\
\hline Vitis & - & 17.0 & - & 1.3 & - & - & 9.3 \\
\hline \multicolumn{8}{|l|}{ Apiaceae } \\
\hline Daucus & - & 10.4 & - & - & - & - & - \\
\hline \multicolumn{8}{|l|}{ Zygophyllaceae } \\
\hline Peganum harmala & - & 24.4 & - & - & - & - & - \\
\hline \multicolumn{8}{|l|}{ Ranunculaceae } \\
\hline Ranunculus & - & - & - & - & - & - & 3.7 \\
\hline
\end{tabular}


Table 2

Antimicrobial effect of honey in Elazığ. (Localities: 1 = Yukarı İçme, 2 = Yolçatı, 3 = Koparuşağ $\breve{1}_{1} 4=$ Harput, 5 = Baunuşađ1, $6=$ Maden, 7 = Sivrice, $8=$ control)

\begin{tabular}{lcccccccc}
\hline & \multicolumn{8}{c}{ Inhibition zone $(\mathrm{mm})$} \\
\cline { 2 - 9 } Microorganisms /Localities & 1 & 2 & 3 & 4 & 5 & 6 & 7 & 8 \\
\hline Escherichia coli ATCC-5922 & - & - & - & 13 & - & 15 & 35 & - \\
Salmonella sp. FMC-20 & - & - & 13 & 14 & - & - & 17 & - \\
Enterobacter aerogenes CCM-2531 & 16 & 16 & 15 & 14 & 16 & 18 & 20 & - \\
Pseudomonas aeruginosa DSM-50071 & 17 & 19 & 15 & 22 & 16 & 17 & 22 & - \\
Bacillus megaterium DSM-32 & 13 & 17 & 12 & 17 & 23 & 20 & 18 & - \\
Bacillus subtilis IMG-22 & 12 & 15 & 13 & 16 & 14 & 17 & 21 & - \\
Staphylococcus aureus COWAN-1 & 13 & 22 & 15 & 16 & 18 & 15 & 26 & \\
Klebsiella pneumoniae FMCS & 15 & 19 & 12 & 21 & 16 & 23 & 19 & - \\
Saccharomyces cerevisiae UAG-102 & - & - & - & - & - & - & - & - \\
Candida albicans FMC-17 & - & - & - & - & - & - & - & - \\
\hline
\end{tabular}

The pollen type of Astragalus was also observed predominantly in light colour honey samples collected in Sivrice and Maden districts of Elazı̆ province. The honey sample represented by Peganum harmala (Zygophyllaceae) collected in Harput (another district of Elazığ ), was found as a dark colour with no taste and aroma.

The antimicrobial effects of honey samples from different local areas of Elazı $\breve{g}$ is summarized in Table 2.

As it can be seen in this table, the antimicrobial effects were various for each sample. All the studied samples did not show any significant effects on S. cerevisiae and C. albicans strains. These results were also supported by other studies (Sorkun and Yuluğ 1985, Çakır and Tümen 1990). But in another study, $0.5 \%$ honey concentration has shown to be effective on $C$. albicans and inhibited the growth of cultured microorganism with $100 \%$ concentration (Dustman 1979).

The honey samples inhibited the growth of E. aerogenes, P. aeroginosa DSM-50071, B. megaterium DSM-32, B. subtilis DSM-22, S. aureus COW$\mathrm{AN}-1$ and K. pneumoniae with a various percentage. Samples from the same areas did not inhibit the growth of E. coli and Salmonella sp.

A study of 10 honey samples collected from Rize region (NE Turkey) was shown that they have no antifungal effects against to $C$. albicans and $C$. tropicalis (Sorkun and Yulug 1985). The growth of Pseudomonas aeruginosa was also not effected in the present of these honey samples. The growing condition of Salmonella flexner, E. coli, S. typhi, P. vulgaris and B. streptococcus were effected at least some stage by honey samples of $9,6,5,5,2$ respec- 
tively. Honey samples, predominantly with pollen of Castanea sativa and Helianthemum have shown the strongest antimicrobial effect (Sorkun and Yuluğ 1985).

In another study in the province of Balikesir (W Turkey), where total 30 honey samples were tested and it was found that, 27 samples have effects on Staphylococcus aureus, 29 on Bacillus subtilis, 27 on Escherichia coli, 28 on Pseudomonas multophica and 21 on Klebsiella pneumoniae. It was reported that the honey samples containing pollen grains of Centaurium spp., Trifolium spp., Cistus creticus, Cistus laurifolius, Rosa canina and Helianthus annuus have wide effects on all these bacteria which are mentioned above. In this study, the fungal effect of this samples have not been detected against to C. albicans MIV-270, T. mentagrophytes, A. niger KUEN-1147 and A. fumigatus KUEN-1145 (Çakır and Tümen 1990).

It was shown that, most of the honey samples have antimicrobial effects against to Gram+ and Gram-bacteria (Ali et al. 1991). Honey samples with $0.5 \%$ concentration have been found to effect a large type of microorganisms (Obeseki-Ebor et al. 1983).

As a result, there was not much difference between data from our study and others done in Turkey. Considering the minor difference in some samples might be from different sample composition.

In this study the honey samples predominant with pollens of Astragalus, Trifolium and Rubus were found to be more effective than others, in antimicrobial effects.

\section{REFERENCES}

Ali, A. T., Chowdhury, M. N. and Humayyad, M. S. (1991): Inhibitory effect of natural honey on Helicobacter pylori. - Trop. Gastroenterol. 12(3): 43-139.

Aytuğ, B. (1967): Polen Morfolojisi ve Türkiye'nin Önemli Gymnospermleri Üzerine Araştırmalar. - İstanbul Üniversitesi Yayın No. 114.

Aytuğ, B., Aykut, S., Merev, N. and Edis, G. (1971): İstanbul Çevresi Bitkilerinin Polen atlası. İstanbul Üniversitesi Yayın No. 1650.

Collins, C. H. and Lyne, P. M. (1985): Microbiological methods. - Butterworth and Co. (Publishers) Ltd., London.

Çakır, H. and Tümen, G. (1990): Balıkesir Yöresi Ballarının Antimikrobiyal ve Antifungal Etkileri. X. - Ulusal Biyoloji Kongresi, Erzurum, 18-20 Temmuz.

Dustman, J. H. (1979): Antibacterial effects of honey. - Apiacta 14: 7-11.

Efem, S. E., Udoh, K. T. and Iwara, C. I. (1992): The antimicrobial spectrum of honey and its clinical significance. - Infection 20(4): 9-227.

Erdtman, G. (1974): An introduction to pollen analysis. - Hafner Press, New York. 
Feller, M. J., Parent, J. and Strachan, A. A. (1987): Microscopic analysis of honey from Alberta, Canada. - J. Apicultural Research 26(2): 123-132.

Feller, M. J., Parent, J. and Strachan, A. A. (1989): Microscopic analysis of honey from Manitoba, Canada. - J. Apicultural Research 28(1): 41-49.

Gemici, Y. (1990): İzmir Yöresi Ballarında Polen Analizi. - Doğa Türk Botanik Dergisi 15: 291-296.

Göçmen, M. and Gökçeoğlu, M. (1991): Bursa Yöresi Ballarında Polen Analizi. - Doğa Türk Botanik Dergisi 16: 373-381.

Huntanen, C. N. (1991): Gamma radiation resistance of Clostridium botilium 62 A and Bacillus subtilis spores in honey. - J. Food Protection 54(11): 894-896.

Louveaux, J., Maurizio, A. and Vorwohl, G. (1970): Methods of melisopalynology. - Bee world 51: 125-138.

Obeseki-Ebor, E. E., Afonya, T. C. A. and Onyekweli, A. O. (1983): Preliminary report on the antimicrobial activity on honey distillate. - J. Pharmacy and Pharmacology 35(11): 748-749.

Özçelik, S. (1992): Gıda Mikrobiyolojisi Laboratuvar Kılavuzu. - Fırat Üniv. Fen-Edebiyat Fakültesi, Yayın No. 1, Elazı̆̆.

Russel, K. M. et.al. (1990): Identification of some bacterial constituents of New Zealand manuka honey. - J. Agricultural and Food Chem. 38(1): 10-13.

Sorkun, K. and İnceoğlu, Ö. (1984): İç Anadolu Bölgesi Ballarında Polen Analizi. - Doğa Bilim Dergisi, Ser. A2, 8(2): 222-228.

Sorkun, K. and Yuluğ, N. (1985): Rize İkizdere Yöresi Ballarının Polen Analizi ve Antimikrobik Özellikleri. - Dŏ̆a Bilim Dergisi, Ser. A2, 9(1): 118-123.

Wodehouse, R. P. (1965): Pollen grains. - Hafner Press, New York. 